\title{
The use of castor oil in the production of $\gamma$-decalactone by Yarrowia lipolytica KKP 379
}

\author{
J. Krzyczkowska \\ Warsaw University of Life Sciences, Faculty of Food Sciences, \\ 159 Nowoursynowska Str., 02-776 Warsaw, Poland \\ E-mail: jolanta_krzyczkowska@sggw.pl \\ cross $^{\text {ref }}$ http://dx.doi.org/10.5755/j01.ct.61.3.2717
}

Received 17 September 2012; Accepted 25 October 2012

The study deals with the ability of the Yarrowia lipolytica KKP 379 strain to gamma-decalactone production by biotransformation of castor oil. The content of gamma-decalactone was verified in the water and lipid phase within 7 days of reaction. On the basis of granulometric analysis, the characteristic of the emulsion was presented. The results confirmed the ability of the Y. lipolytica $379 \mathrm{KKP}$ strain to produce gamma-decalactone in the amount of about $1.68 \mathrm{~g} / \mathrm{l}$. The granulometric analysis revealed two populations of fatty droplets in $4.5 \mu \mathrm{m}$ and $580 \mu \mathrm{m}$ size.

Key words: $\gamma$-decalactone, castor oil, biotransformation, Yarrowia lipolytica

\section{Introduction}

The biotechnological production of flavour and fragrance compounds is an excellent alternative to both the extraction of plant materials and a typical chemical synthesis. In the recent years, a growing interest to the biosynthesis of fragrances can be observed.

A popular aroma compound used both in food and cosmetic industry is the $\gamma$-decalactone which is characterized by a peach smell.

This compound can be obtained by biotransformation of ricinoleic acid (12-hydroxyoctadec-9-enoic acid) [1-2] which is a major component (about $80 \%$ ) of castor oil, a natural and non-toxic oil, biodegradable and a renewable resource obtained from seeds of the castor plant Ricinus communis [3]. The process involves substrate biodegradation through peroximal $\beta$-oxidation, leading to the formation of 4-hydroxydecanoic acid, which cyclizes into $\gamma$-decalactone (Fig. 1) [4-5].

So far, in the biotechnological production of $\gamma$ decalactone following yeast genera have been used: Sporidiobolus [2], Pichia [3], Rhodotorula [7], Candida, and Yarrowia. Nevertheless, especially high prospects are associated with the latter microorganisms, namely nonconventional yeast Yarrowia lipolytica, considered as a non-pathogenic and as GRAS by the American Food and Drug Administration.

The aim of this study was to evaluate the ability of the yeast Yarrowia lipolytica KKP 379 to produce of $\gamma$-decalactone. An oil-in-water emulsion, stabilized by the nonionic surfactant Tween 80, was used in biotransformation reactions. In this type of culture, the contact surface of fat droplets with cells of propagated microorganisms and the surface between two liquid phases are the determining factors in the degradation of a hydrophobic substrate, and thus in the cell growth and aroma production by these cells. The emulsion was characterized by determining the oil droplet size distribution by the laser granulometry technique.

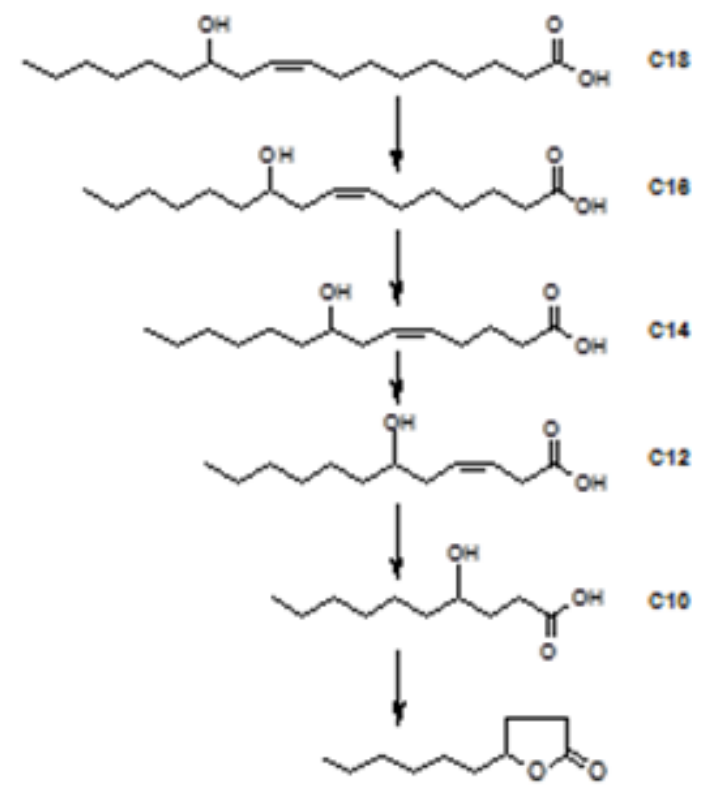

Fig. 1. Fatty acids observed as intermediates in the biotransformation of ricinoleic acid (18 carbons) into $\gamma$-decalactone (10 carbons) [6]

\section{Materials and methods}

Microorganism, media, and culture conditions

Yarrowia lipolytica KKP 379 was obtained from the microbial culture collection of the Agricultural and Food Biotechnology Institute of Warsaw (Poland). The yeast was cultured for $48 \mathrm{~h}$ on the YPDA medium (agar $20 \mathrm{~g} / \mathrm{l}$, glucose $20 \mathrm{~g} / \mathrm{l}$, peptone $20 \mathrm{~g} / \mathrm{l}$, yeast extract $10 \mathrm{~g} / \mathrm{l}$ ) at $27^{\circ} \mathrm{C}$ and used to inoculate (to reach $\mathrm{OD}_{600}$ of about 0.25 ) $500 \mathrm{ml}$ baffled Erlenmeyer flasks containing $200 \mathrm{ml}$ of the 
YPD medium (glucose $20 \mathrm{~g} / \mathrm{l}$, peptone $20 \mathrm{~g} / \mathrm{l}$, yeast extract $10 \mathrm{~g} / \mathrm{l})$. Flasks were shaken at $140 \mathrm{rpm}$ and $27^{\circ} \mathrm{C}$ for $19 \mathrm{~h}$ until the cultures reached the late-logarithmic growth phase. There suspensions were used to inoculate the biotransformation media.

\section{Biotransformation of castor oil into $\gamma$-decalactone}

For $\gamma$-decalactone production, the cells in late growthphase $(19 \mathrm{~h})$ were transferred to the biotransformation medium at the initial concentration of $10^{8}$ cells $/ \mathrm{ml}$. This medium was composed of castor oil (Sigma-Aldrich) at $100 \mathrm{~g} / \mathrm{l}$, peptone $20 \mathrm{~g} / \mathrm{l}$, and Tween 80 (4-5 droplets per $100 \mathrm{ml}$ ). The biotransformation was then conducted in $250 \mathrm{ml}$ baffled Erlenmeyer flasks $\left(27^{\circ} \mathrm{C}, 140 \mathrm{rpm}\right.$ for 7 days).

\section{$\gamma$-Decalactone extraction and quantification}

For the quantification of $\gamma$-decalactone, $1.5 \mathrm{ml}$ samples were collected regularly from the culture medium for 7 days. In order to stop the metabolism and achieve the overall lactonization of 4-hydroxydecanoic acids, $10 \mathrm{ml}$ of $\mathrm{HCl}(6 \mathrm{~N})$ were added to the samples. Then $\gamma$-undecalactone was introduced as an internal standard. The samples were extracted with $1.5 \mathrm{ml}$ of diethyl ether. After 5 min, the ether phase was separated and analyzed by GC (Varian 3800 instrument) with a TR-WAX capillary column and with $\mathrm{He}$ as the carrier gas. The temperatures of the split injector and the detector were set at $250{ }^{\circ} \mathrm{C}$ and $300^{\circ} \mathrm{C}$, respectively. The oven temperature was programmed to increase from $75^{\circ} \mathrm{C}$ to $135^{\circ} \mathrm{C}$ at a rate of $6^{\circ} \mathrm{C} \min ^{-1}$, next to $180{ }^{\circ} \mathrm{C}$ at a rate of $3{ }^{\circ} \mathrm{C} \min ^{-1}$ and then to $250{ }^{\circ} \mathrm{C}$ at a rate of $5{ }^{\circ} \mathrm{C} \min ^{-1}$. All assays were performed in triplicate.

Laser granulometry

The size of the yeast cells and of the fatty acid droplets in the medium was evaluated by Malvern Mastersizer 2000 laser granulometry measurements.

\section{Results and discussion}

In assessing the capacity of the yeast Yarrowia lipolytica KKP 379 for the biotransformation of ricinoleic acid, the content of $\gamma$-decalactone was verified within seven days of culture, both in the lipid and aqueous phases. As shown in Fig. 2, the strain Yarrowia lipolytica KKP 379 is capable of producing $\gamma$-decalactone, even in the total amount of about $1.68 \mathrm{~g} / 1$.

The maximum reaction efficiency falls on the 5th day of the culture when the content of $\gamma$-decalactone reaches the approximate level (about $0.8 \mathrm{~g} / \mathrm{l}$ ) both in the aqueous and lipid phases. In the early days of culture, $\gamma$-decalactone is mainly accumulated in the aqueous phase. During this period, its level in this phase is up to three times higher than in the lipid phase. In the final times of culture, $\gamma$-decalactone prevails in the lipid phase (the level is higher by about $30 \%$ ), but its content with the increasing cultivation time over five days is decreasing. It is assumed that this is related to the influence of $\mathrm{pH}$ of the medium. Waché et al. [5] indicate that the $\mathrm{pH}$ value can have a significant impact on $\gamma$-decalactone reconsumption. The decline of $\gamma$-decalactone is associated with the penetration of this compound into the yeast cells and its hydrolysis, which can occur at a low $\mathrm{pH}(\mathrm{pH} 2-4)$ observed in the final stage of the culture.

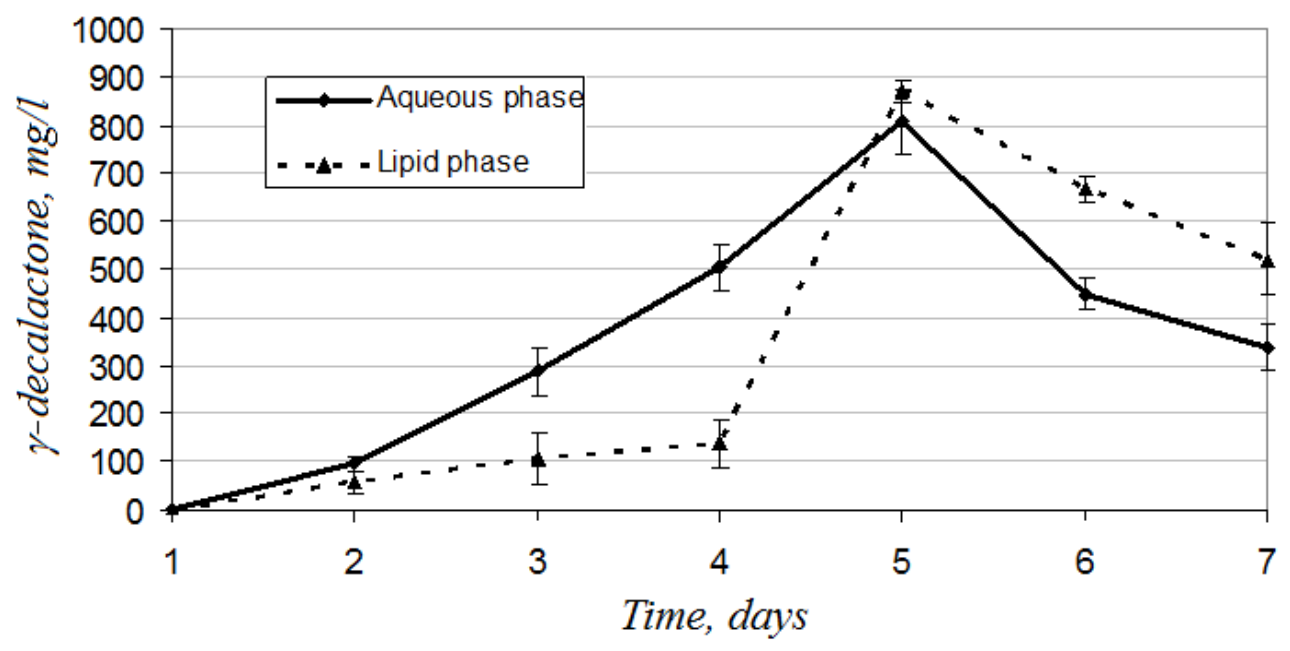

Fig. 2. Accumulation of $\gamma$-decalactone in aqueous $(\diamond)$ and lipid $(\boldsymbol{\Delta})$ phase during the growth of Yarrowia lipolytica KKP 379 strain on $100 \mathrm{ml}$ medium with castor oil $(100 \mathrm{~g} / \mathrm{l})$

In assessing the ability of the Yarrowia lipolytica KKP 379 strain to the production of $\gamma$-decalactone by biotransformation of castor oil, the emulsion building the medium was also characterized.
The granulometric analysis of the emulsified castor oil medium with cells indicated the existence of two distinct droplet populations (Fig. 3). 


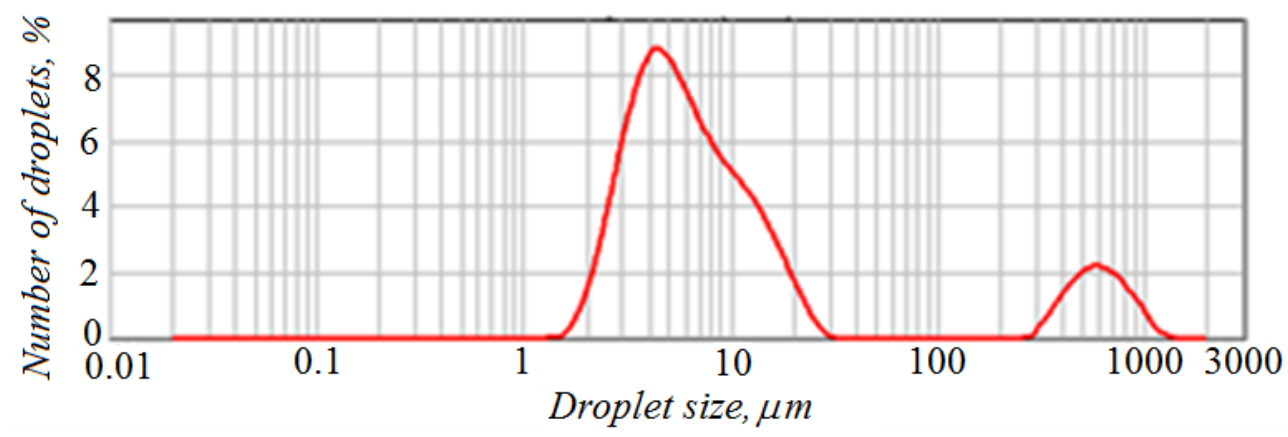

Fig. 3. Castor oil droplet size distribution (in $\mu \mathrm{m}$ ) in emulsion with cells, related to the number of particles (in \%). Data are the mean of three independent experiments

In a larger population, the droplet mean values of $4.5 \mu \mathrm{m}$ were detected. To estimate the size of yeast cells, the granulometric analysis was also made after their suspension in distilled water. In this measurement, the population with the mean value of $5.3 \mu \mathrm{m}$ was observed. These results are consistent with the data on cell size, reported by Gomes et al. [8] using a granulometric laser. It is assumed that in the area of the larger size population also the smallest oil droplets are present, which can be obscured by a large number of yeast cells. It is probable that some of the fat globules undergo adhesion to the cell surface. Another population presented in the graph (Fig. 3) corresponds to a fairly large fat droplet size - within about $580 \mu \mathrm{m}$.

The size of fat droplets in the medium depends on the physical and physicochemical properties of the medium ( $\mathrm{pH}$, ionic strength, presence of surfactants), the amount of

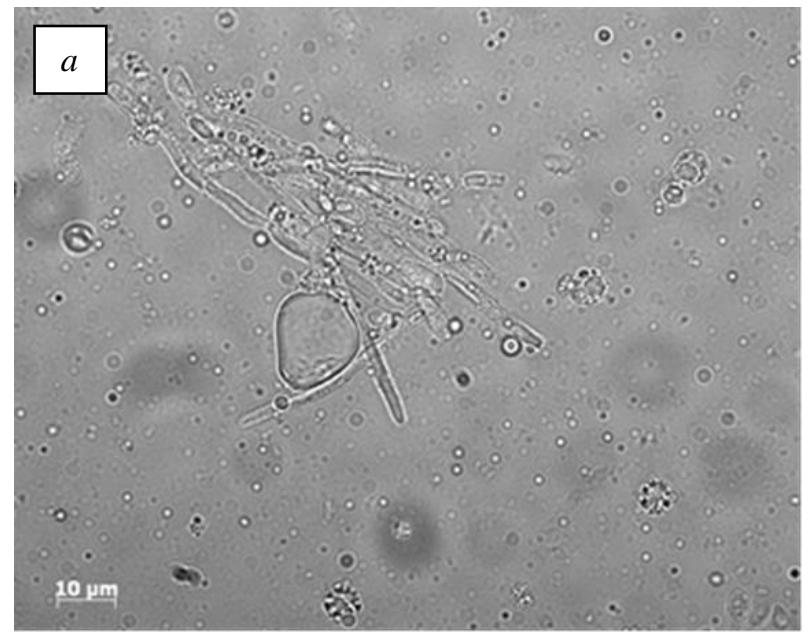

the inoculum introduced into the culture medium, and the surface properties of propagated cells [9].

In order to confirm that during the biotransformation of ricinoleic acid by microorganism cells, because of direct contact with the hydrophobic substrate, some cells undergo adhesion to the surface of the lipid substrate, and some of the oil droplets are adsorbed on the surface of the microorganism cells. Therefore, the microscopic observations of yeast were made. The figure on the left is a real picture of the yeast cells (Fig. 4a), and the figure on the right shows the cells colored with calcofluor-white (Fig. 4b). In the picture, it is clearly visible that fat droplets are adsorbed to the surface of the cells which appear both in the form of yeast and mycelia. In the case of yeast Yarrowia lipolytica KKP 379, one can see that the cells undergo a strong aggregation and have a tendency to agglomerate around the fat droplets.

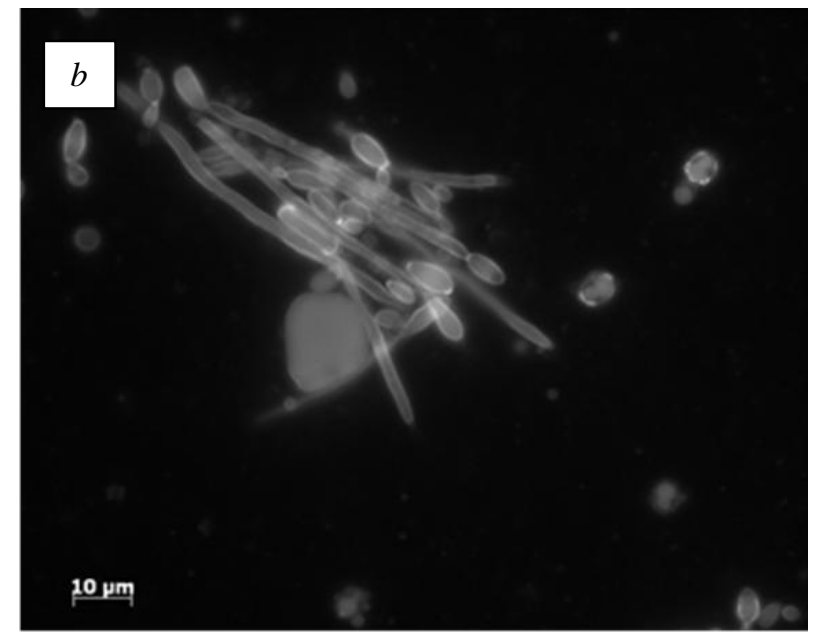

Fig. 4. Microscopy observation of Yarrowia lipolytica KKP 379 after 7 days of culture on castor oil: $a$-real picture of the yeast cells; $b$-cells coloured with calcofluor-white

\section{Conclusions}

The Yarrowia lipolytica KKP 379 strain is able to produce $\gamma$-decalactone by castor oil biotransformation. The synthesis of the aroma is possible within five days of reaction. During this period, gamma-decalactone is accumulated mainly in the water phase. The granulomeric analysis is a convenient tool for better understanding the assimilation of hydrophobic substrates by the yeast Yarrowia lipolytica KKP 379.

\section{Acknowledgements}

This research was financially supported by the Ministry of Science and Higher Education (Grant No. N N209 107639). 


\section{References}

1. Alchihab M., Destain J., Aguedo M., Thonart P. Production d'arômes de type lactone par des levures. Biotechnol. Agron. Soc. Environ. 2010. Vol. 14. P. 681691.

2. Blin-Perrin C., Molle D., Dufosse L., Le-Quere J. L., Viel C., Mauvais G., FeronG. Metabolism of ricinoleic acid into $\gamma$-decalactone: $\beta$-oxidation and long chain acyl intermediates of ricinoleic acid in the genus Sporidiobolus sp. FEMS Microbiol. Lett. 2000. Vol. 188. P. 69-74.

3. Waché Y., Husson F., Feron G., Belin J-M. Yeast as an efficient biocatalyst for the production of lipid-derived flavours and fragrances. Antonie van Leewenhoek. 2006. Vol. 89. P. 405-416.

http://dx.doi.org/10.1007/s10482-005-9049-3

4. Gomes N., Teixeira J. A., Belo I. The use of methyl ricinoleate in lactone production by Yarrowialipolytica: Aspects of bioprocess operation that influence the overall performance. Biocatal. Biotrans. 2010. Vol. 28. P. 227-234. http://dx.doi.org/10.3109/10242422.2010.493208

5. Waché Y., Aguedo M., LeDall M. T., Nicaud J. M., Belin J. M. Optimization of Yarrowialipolytica's $\beta$ oxidation pathway for $\gamma$-decalactone production. J. Mol. Catal. B: Eznym. 2002. Vol. 19-20. P. 347-351. http://dx.doi.org/10.1016/S1381-1177(02)00185-6

6. Aguedo M., Waché Y., Coste F., Husson F., Belin J. M. Impact of surfactants on the biotransformation of methyl ricinoleate into $\gamma$-decalactone by Yarrowialipolytica. J. Mol. Catal. B: Enzym. 2004. Vol. 29. P. 31-36. http://dx.doi.org/10.1016/j.molcatb.2003.11.018

7. Alchihab M., Aldric J. M., Augedo M., Destain J., Wathelet J. P, Thonart P. The use of Macronet resins to recover $\gamma$-decalactone produced by Rhodotorulaaurantiaca from the culture broth. J. Ind. Microbiol. Biotechnol. 2010. Vol. 37. P. 167-172.

http://dx.doi.org/10.1007/s10295-009-0659-z

8. Gomes N., Waché Y., Teixeira J. A. Belo I. Oil-water emulsions characterization by laser granulometry and impact on $\gamma$-decalactone production in Yarrowialipolytica. Biotechnol. Lett. 2011. Vol. 33. P. 1601-1606. http://dx.doi.org/10.1007/s10529-011-0593-9
9. Garcia E. E., Aguedo M., Gomes N., Choquet A., Belo I., Teixeira J. A., Belin J. M., Waché Y. Production of 3hydroxy- $\gamma$-decalactone, the precursor of two decenolides with flavouring properties, by the yeast Yarrowialipolytica. Journal of Molecular Catalysis B: Enzymatic. 2009. Vol. 57. P. 22-26.

http://dx.doi.org/10.1016/j.molcatb.2008.06.010

J. Krzyczkowska

RICINOS ALIEJAUS PANAUDOJIMAS
-DEKALAKTONO GAMYBAI YARROWIA
LIPOLYTICA KKP 379

\section{S a n t r a u a}

Buvo nagrinèta Yarrowia lipolytica KKP 379 geba biotransformuojant ricinmedžio aliejų $\gamma$-dekalaktonui pagaminti. Jo susidarymas vandens ir riebalų fazèse tirtas procesui vykstant 7 paras. Didžiausia reakcijos išeiga stebima penktą proceso parą, $\gamma$-dekalaktono kiekis abiejose fazėse tuo metu apytiksliai yra po $0,8 \mathrm{~g} / \mathrm{l}$. Pirmosiomis dienomis $\gamma$-dekalaktonas daugiausiai kaupiasi vandens fazèje, vèliau jo kiekis didejja riebalų fazèje. Po 5 parų bendrasis produkto kiekis pradeda mažèti.

Granuliometrinè biotransformuoto ricinos aliejaus emulsijos analizė parodè, kad susidaro dvi riebalų lašelių grupès, kurių dydis 4,5 ir $580 \mu \mathrm{m}$. 